\title{
Hubungan Paparan Pestisida dengan Kadar SGOT dan SGPT Petani di Desa Pakis Kabupaten Jember
}

\author{
Iin Fatimatus Zahrox ${ }^{1}$, Hairrudin ${ }^{2 *}$, Kristianningrum Dian Sofiana ${ }^{3}$ \\ ${ }^{1}$ Program Studi Pendidikan Dokter, Universitas Jember \\ ${ }^{2}$ Laboratorium Biokimia, Fakultas Kedokteran Universitas Jember \\ ${ }^{3}$ Laboratorium Fisiologi, Fakultas Kedokteran Universitas Jember \\ *Corresponding Author: hairrudin.fk@unej.ac.id
}

Info Artikel : Diterima 20 Mei 2020 ; Disetujui 11 November 2020 ; Publikasi 1 April 2021

Cara sitasi (Vancouver): Zahrox IF, Hairrudin H, Sofiana KD. Hubungan Paparan Pestisida dengan Kadar SGOT dan SGPT Petani di Desa Pakis Kabupaten Jember. Jurnal Kesehatan Lingkungan Indonesia [Online]. 2021 Feb;20(1):47-52. https://doi.org/10.14710/jkli.20.1.47-52.

\begin{abstract}
ABSTRAK
Latar belakang: Hepar merupakan salah satu organ yang rentan terhadap paparan pestisida. Akumulasi pestisida di dalam hepar tidak dapat diuraikan maupun diekskresikan. Penumpukan pestisida pada hepar memicu peningkatan jumlah radikal bebas dan menyebabkan gangguan permeabilitas membran sel hepatosit. Kondisi tersebut mengakibatkan kerusakan sel hepatosit dan meningkatkan kadar SGOT maupun SGPT. Desa Pakis merupakan salah satu desa penghasil padi terbesar di Kabupaten jember dengan mayoritas penduduk bekerja sebagai petani. Penelitian ini bertujuan untuk menganalisis hubungan paparan pestisida terhadap kadar SGOT dan SGPT pada petani di Desa Pakis Kabupaten Jember.

Metode: Penelitian ini merupakan penelitian observasional analitik dengan desain penelitian cross sectional. Sampel pada penelitian ini adalah petani padi Desa Pakis yang menggunakan pestisida organofosfat atau karbamat Pengambilan sampel dilakukan menggunakan teknik non probability sampling dengan metode accidental sampling. Data diperoleh melalui wawancara dan pengukuran kadar asetilkolinesterase, SGOT dan SGPT menggunakan fotometer.

Hasil: Sampel berjumlah 30 orang. Tingkat paparan pestisida yang tinggi ditunjukkan oleh kadar asetilkolinesterase $<75 \%$ ditemukan pada 23,33\% dari sampel. Sebagian besar berusia > 50 tahun dan telah bekerja lebih dari 10 tahun. Peningkatan kadar SGOT dan SGPT didapatkan masing-masing sebesar 33,33\% dan $23,33 \%$. Hasil penelitian menunjukkan bahwa tidak ada hubungan yang signifikan antara paparan pestisida dengan kadar SGOT $(p=0,320)$ dan SGPT $(p=604)$.

Simpulan: Tidak ada hubungan antara paparan pestisida dengan kadar SGOT dan SGPT pada petani di Desa Pakis Kabupaten Jember.
\end{abstract}

Kata kunci: Pestisida; Kolinesterase; Organopospat; SGOT; SGPT.

\section{ABSTRACT}

Title: The Correlation of Pesticides Exposure with Farmer's SGOT and SGPT level in Pakis Village, Jember Regency

Background: The Liver is one of the organs that are vulnerable to pesticide exposure. Accumulated pesticides in the liver cannot be broken down or excreted. Pesticides that build up in the liver triggers an increase in the number of free radicals and cause an impaired hepatocyte membrane permeability. These conditions result in damage to hepatocyte cells and an increase in SGOT/SGPT levels. Pakis village is one of the biggest paddy producers in Kabupaten Jember with the majority of its people works as farmers. This research aims to analyze the correlation of pesticide exposure and SGOT/SGPT levels among farmers in Pakis village, Jember regency. 
Method: This research is an analytic observational study using a cross-sectional research design. Samples were farmers who had been using organophosphate or carbamate pesticides. Sample collected using a nonprobability sampling technique with the accidental sampling method. Data obtained through interviews and measurements of acetylcholinesterase, SGOT, and SGPT levels using a photometer.

Result: A number of 30 subjects participated. A high degree of pesticide exposure as indicated by acetylcholinesterase level of $<75 \%$ was encountered in $23.33 \%$ of samples. Most samples were > 50 years old and had worked for more than 10 years. Increased SGOT and SGPT levels were encountered in 33.33\% and $23.33 \%$, respectively. This research has shown that there was no significant correlation between pesticide exposure with SGOT $(p=0,320)$ and SGPT levels $(p=604)$.

Conclusion: No significant correlations were found between pesticides exposure with SGOT and SGPT levels in farmers in Pakis village, Jember regency.

Keywords: Pesticides; Cholinesterase; Organophosphate; SGOT; SGPT

\section{PENDAHULUAN}

Keracunan organofosfat akut merupakan salah satu ancaman global terhadap kesehatan manusia yang mengakibatkan 100.000 kematian per tahun. ${ }^{1}$ WHO memperkirakan terdapat sekitar 1-5 juta kasus keracunan pestisida yang terjadi pada petani dan sebagian besar kasus tersebut terjadi di negara berkembang. ${ }^{2}$ Pestisida organofosfat sering digunakan oleh petani untuk membasmi serangga karena mempunyai senyawa yang stabil di lingkungan.,

Pestisida golongan organofosfat dan karbamat merupakan pestisida yang berkerja dengan cara mempengaruhi sistem saraf organisme terpapar, dengan menghambat enzim acetylcholinesterase sehingga meningkatkan kadar asetilkolin pada sinaps kolinergik (AChE). ${ }^{4,6}$ Aktivitas asetilkolinesterase akan tetap dihambat hingga enzim baru terbentuk. Hal tersebut menyebabkan penumpukan asetilkolin pada sinaps-sinaps kolinergik dan menimbulkan gejalagejala keracunan pestisida., 3,6

Keracunan pestisida organofosfat lebih mudah dimonitor melalui kadar asetilkolinesterase dalam darah sebagai biomarker keracunan pestisida organofosfat dan atau karbamat. ${ }^{6,7}$ Pestisida umumnya masuk kedalam tubuh melalui kulit, mata, inhalasi atau tertelan sehingga dapat mencapai organ target. ${ }^{6,8}$ Salah satu organ yang rentan terhadap paparan pestisida adalah hepar karena berperan sebagai pusat metabolisme protein, lemak, karbohidrat serta pusat detoksifikasi zat beracun dalam tubuh.,

Akumulasi paparan pestisida yang masuk ke dalam hepar tidak dapat diuraikan maupun dieksresikan sehingga meningkatkan jumlah radikal bebas dalam tubuh yang akan menyebabkan stres oksidatif. Radikal bebas menyerang senyawa-senyawa penyusun sel. Senyawa yang rentan dari serangan radikal bebas misalnya poly unsaturated fatty acid (PUFA). Serangan tersebut dapat mengakibatkan kerusakan parenkim hepar atau gangguan permeabilitas membran sel hepar sehingga enzim aminotransferase yang pada keadaan normal berada di dalam sel (sitoplasma) keluar dalam darah. Hal tersebut akan meningkatkan kadar Serum Glutamat Oksaloasetat Transaminase (SGOT) dan Serum
Glutamat Piruvat Transaminase (SGPT) sebagai salah satu tanda kerusakan hepar. ${ }^{10.11}$

Berdasarkan data Badan Pusat Statistik (2019), salah satu daerah di Kabupaten Jember yang menggunakan pestisida organofosfat sebagai pembasmi hama yaitu Desa Pakis. Desa Pakis merupakan salah satu desa penghasil padi terbesar di Kecamatan Panti Kabupaten Jember dengan mayoritas penduduknya bekerja sebagai petani. $^{12}$ Kejadian keracunan pestisida dapat terjadi pada petani yang kurang memperhatikan penggunaan alat pelindung diri (APD) ${ }^{13}$, penggunaan dosis dan frekuensi yang tidak sesuai ${ }^{13}$, cara dan waktu penyemprotan yang tidak tepat serta penyimpanan pestisida yang tidak benar. ${ }^{4,6}$ Sampai saat ini data tentang hubungan tingkat paparan pestisida terhadap kadar SGOT dan SGPT di daerah tersebut belum diketahui sehingga penelitian ini dilakukan untuk mengetahui hubungan tingkat paparan pestisida terhadap kadar SGOT dan SGPT pada petani di Desa Pakis Kabupaten Jember.

\section{BAHAN DAN METODE}

Penelitian ini merupakan penelitian observasional analitik dengan desain penelitian cross sectional. Populasi dalam penelitian ini adalah petani padi yang menggunakan pestisida organofosfat dan atau karbamat di Desa Pakis Kecamatan Panti Kabupaten Jember. Sampel yang diambil adalah petani padi yang menggunakan pestisida organofosfat dan atau karbamat di Desa Pakis yang memenuhi krieteria inklusi, yaitu: 1) mampu berkomunikasi dengan baik, 2) memberikan persetujuan dengan menandatangani informed consent.

Besar sampel pada penelitian ini sejumlah 30 orang yang diambil melalui teknik non probability sampling dengan metode accidental sampling. Data yang digunakan merupakan data primer yang diperoleh melalui wawancara dan pemeriksaan laboratorium. Sampel darah diambil dari pembuluh darah vena. Kadar acetilkolinesrterase, SGOT dan SGPT diukur menggunakan spektrofotometer. Kadar kolinesterase diukur menggunakan metode standar optimal rekomendasi German Society of Clinical Chemistry (DGKC) ${ }^{14}$ sedangkan SGOT dan SGPT menggunakan metode kinetik-IFCC. ${ }^{15}$ Data yang 
didapat terdistribusi normal, selanjutnya dianalisis dilakukan secara univariat dan bivariat.

\section{HASIL DAN PEMBAHASAN}

Data yang digunakan pada penelitian ini merupakan data primer yang meliputi hasil pemeriksaan kadar asetilkolinesterase sebagai biomarker keracunan pestisida, kadar SGOT dan SGPT, serta kuesioner. Karakteristik sampel pada penelitian ini digolongkan berdasarkan jenis kelamin, usia, masa kerja, dan riwayat penyakit. Data karakteristik sampel pada penelitian ini dapat dilihat pada Tabel 1. Data kadar asetilkolinesterase dapat dilihat pada Tabel 2.

Nilai normal asetilkolinesterase pada laki-laki adalah 4.620 U/L sampai 11.500 U/L, sedangkan nilai normal pada perempuan adalah $3.930 \mathrm{U} / \mathrm{L}$ sampai 11.800 U/L. ${ }^{16}$ Kadar asetilkolinesterase $<75 \%$ dibawah nilai normal dapat digunakan sebagai biomarker keracunan pestisida. Kejadian keracunan yang diukur melalui aktivitas asetilkolinesterase dalam darah yang dapat dijadikan indikator paparan pestisida. $^{6,7}$

Tabel 1. Data karakteristik sampel

\begin{tabular}{lcc}
\hline \multicolumn{1}{c}{ Karakteristik Sampel } & Jumlah $(\mathrm{n})$ & Persentase $(\%)$ \\
\hline Jenis kelamin & 18 & 60 \\
$\quad$ Laki-laki & 12 & 40 \\
Perempuan & & \\
Usia & 2 & 06,67 \\
21-30 tahun & 2 & 06,67 \\
$31-40$ tahun & 10 & 33,33 \\
$41-50$ tahun & 11 & 36,67 \\
$51-60$ tahun & 5 & 16,67 \\
$>60$ tahun & & 16,67 \\
Masa kerja & 5 & 83,33 \\
$\quad<5$ tahun & 25 & \\
$>10$ tahun & & 66,67 \\
Riwayat penyakit & 20 & 03,33 \\
Tidak ada & 1 & 30,00 \\
Alergi & 9 & 100 \\
Hipertensi & 30 & \\
\hline Total & & \\
\hline
\end{tabular}

Tabel 2. Distribusi kadar asetilkolinesterase terhadap usia dan masa bekerja

\begin{tabular}{lcccc}
\hline \multirow{2}{*}{ Kriteria } & \multicolumn{4}{c}{ Kadar Asetilkolinesterase yang Aktif } \\
\cline { 2 - 5 } & $275 \%$ & $<75 \%-250 \%$ & $<50 \%-\geq 25 \%$ & $<25 \%$ \\
\hline Tingkat Keracunan & Normal & Ringan & Sedang & Berat \\
Jumlah & 23 & 1 & 1 & 5 \\
Usia & & & & \\
$\quad 21-30$ tahun & 2 & 0 & 0 & 0 \\
31-40 tahun & 2 & 0 & 0 & 0 \\
41-50 tahun & 8 & 0 & 1 & 1 \\
51-60 tahun & 8 & 0 & 0 & 3 \\
$\quad>60$ tahun & 0 & 1 & 0 & 1 \\
Masa Bekerja & & & & \\
$\quad<5$ tahun & 4 & 0 & 0 & 1 \\
$\quad>10$ tahun & 19 & 1 & 1 & 4 \\
\hline
\end{tabular}

Hasil penelitian ini menunjukkan bahwa jumlah lakilaki lebih banyak daripada perempuan. Responden laki-laki sebanyak $60 \%$, sedangkan perempuan sebanyak $40 \%$. Hasil pada penelitian ini hampir sama dengan hasil penelitian Tambunan dkk (2020) yang menunjukkan bahwa jumlah petani laki-laki lebih banyak, yaitu 55\%. ${ }^{17}$ Mayoritas sampel yang bekerja sebagai petani berjenis kelamin laki-laki karena aktivitas pertanian terutama yang berhubungan dengan penyemprotan pestisida merupakan kegiatan fisik yang berat. Hal tersebut diakibatkan tingginya beban fisik pada saat penyemprotan.

Sebagian besar responden $(83,33 \%)$ telah bekerja sebagai petani lebih dari 10 tahun. Fakta ini menunjukkan bahwa sebagian besar responden terpapar pestisida dalam jangka waktu yang lama (paparan kronik). Penelitian sebelumnya membuktikan bahwa terdapat hubungan yang bermakna antara masa kerja dengan kadar kolinesterase. Semakin lama masa kerja 
mengakibatkan paparan kronik dapat meningkatkan akumulasi pestisida dalam tubuh petani sehingga risiko keracunan pada petani juga semakin meningkat dan ditandai dengan makin rendahnya kadar asetilkolinesterase. ${ }^{18}$

Data penelitian pada tabel 2 menunjukkan bahwa $85,7 \%$ petani yang memiliki kadar asetilkolinesterase tidak normal bekerja lebih dari 10 tahun. Dari jumlah tersebut $2 / 3$ petani mengalami keracunan berat. Hal ini disebakan makin lama masa bekerja maka kemungkinan mengalami paparan kronik makin besar sehingga tingkat keracunannya juga makin tinggi.

Faktor usia juga menentukan tingkat keracunan pestisida. ${ }^{19}$ Persentase responden yang berusia $\geq 50$ tahun pada penelitian adalah 50\%. Hal tersebut menunjukkan bahwa di daerah tersebut banyak petani berusia lanjut yang masih bekerja. Semakin tua seseorang maka tingkat keracunan akan semakin tinggi dikarenakan daya tahan dan metabolisme tubuh yang mulai menurun. ${ }^{17}$ Selain itu semakin tua usia seseorang maka akan terjadi penurunan fungsi organ dalam tubuh seperti hepar dan ginjal dengan disertai penurunan kadar asetilkolinesterase. ${ }^{19,20}$

Pengaruh usia terhadap tingkat keracunan pestisida dapat dilihat pada tabel 2. Sebagian besar responden yang mengalami keracunan pestisida $(>70 \%)$ berusia di atas 50 tahun. Semua responden dengan kategori keracunan berat memiliki rentang usia $\geq 50$ tahun. Hasil ini menunjukkan semakin tinggi usia responden makin tinggi pula kemungkinan mengalami keracunan pestisida.

Pada tabel 2 yaitu hasil pemeriksaan kadar asetilkolinesterase menunjukkan sejumlah 23 orang memiliki kadar asetilkolinesterase yang normal. Sedangkan 7 orang $(23,33 \%)$ lainnya memiliki kadar asetilkolinesterase $<75 \%$ dibawah nilai normal dengan rincian 5 orang dalam kategori keracunan berat, 1 orang dalam kategori keracunan sedang dan 1 orang dalam kategori keracunan ringan. Petani yang dinyatakan terpapar pestisida dapat disebabkan oleh peran pestisida organofosfat sebagai inhibitor pada enzim asetilkolinesterase yang dapat bersifat irreversible. $^{3,6}$ Hal ini dapat mengakibatkan penumpukan asetilkolin dan penurunan kadar asetilkolinesterase dalam darah. ${ }^{18}$ Kadar asetilkolinesterase akan pulih minimal empat minggu hingga beberapa bulan tanpa pajanan ulang. ${ }^{3}$ Hal ini menjadi dasar untuk mengetahui kadar asetilkolinesterase normal, yaitu pengukuran harus dilakukan pada kondisi tanpa paparan pestisida selama minimal 30 hari. $^{6}$

Sebagian besar petani pada penelitian ini, yaitu 76,67\% memiliki kadar asetilkolinesterase normal. Petani dengan kadar asetilkolinesterase yang normal dapat diakibatkan oleh paparan pestisida dalam jumlah yang rendah dan telah terbentuk enzim yang baru. Petani yang mengalami keracunan berat dapat diakibatkan oleh paparan pestisida dalam jumlah yang besar maupun mengalami paparan berulang sehingga sintesis enzim baru belum terbentuk. Kedua hal tersebut tergantung pada lama dan frekuensi paparan. ${ }^{13}$

Petani yang menjadi responden adalah patani padi yang sebagian besar memiliki lahan yang sempit. Hal ini mempengaruhi lama dan frekuansi penyenprotan pestisida. Lama $^{21}$ dan frekuensi ${ }^{6,13}$ penyemprotan berhubungan dengan tingkat keracunan. Makin sempit lahan yang dimiliki maka makin singkat lama paparan dengan pestisida sehingga dampaknya juga lebih kecil. ${ }^{19,21}$ Keracunan pestisida berkorelasi dengan area penyemprotan. ${ }^{19}$ Petani padi melakukan penyemprotan menggunakan organopospat dan atau karbamat sekitar dua kali dalam satu periode tanam. Periode tanam padi membutuhkan waktu empat bulan. Rata-rata penyemprotan adalah dua bulan sekali. Paparan dengan selang waktu dua bulan cukup untuk mengembalikan asetilkolinesterase kepada kadar normal. $^{3,6}$ Fakta-fakta tersebut mengakibatkan sebagian besar responden memiliki kadar asetilkolinesterase yang normal.

Hasil penelitian kadar asetilkolinesterase ini hampir sama dengan penelitian yang dilakuan oleh Marisa dan Pratuna (2018) pada petani kentang di kilometer XI di Sungai Penuh yang menunjukkan bahwa terdapat 21 orang dengan kadar asetilkolinesterase normal dan 9 orang (30\%) dengan penurunan kadar asetilkolinesterase..$^{7}$ Pada penelitian yang dilakukan oleh Marisa dan Pratuna membuktikan penurunan kadar asetilkolinesterase diakibatkan minimnya penggunaan APD. Berdasarkan hasil wawancara pada penelitian ini didapatkan bahwa seluruh sampel tidak menggunakan APD dengan lengkap. Hasil ini menunjukkan penurunan kadar asetilkolinesterase yang terjadi disebabkan oleh faktor selain penggunaan APD. Dua faktor yang diduga memiliki hubungan kuat adalah lama paparan $^{21}$ dan usia $^{19}$.

Hasil pengukuran kadar SGOT dan SGPT dapat dilihat pada tabel 3. Dari tabel tersebut dapat diketahui data hasil pemeriksaan kadar SGOT menunjukkan sebanyak 20 orang $(66,67 \%)$ memiliki kadar SGOT normal $(<35 \mu / \mathrm{L})$, sedangkan sejumlah 10 orang sisanya $(33,33 \%)$ mengalami peningkatan kadar SGOT dengan rincian 9 orang mengalami peningkatan kurang dari 1,5 kali dari nilai normal dan 1 orang mengalami peningkatan $>10 x$ nilai normal. Kadar SGOT yang meningkat tidak hanya disebabkan oleh gangguan fungsi hepar tetapi juga disebabkan oleh beberapa faktor seperti, aktivitas, kehamilan, operasi, luka bakar, obat-obatan, infark miokard, pankreatitis akut, trauma, anemia hemolitik akut, penyakit ginjal akut dan penyakit muskuloskeletal. ${ }^{3}$ Pada penelitian ini sebagian besar faktor-faktor tersebut dikendalikan sehingga kadar SGOT dan SGPT yang meningkat lebih mengarah pada gangguan fungsi hepar. 
Tabel 3. Data kadar asetilkolinesterase, SGOT, dan SGPT

\begin{tabular}{lccccc}
\hline \multirow{2}{*}{ Kadar Asetilkolinesterase } & \multirow{2}{*}{ Jumlah } & \multicolumn{2}{c}{ SGOT } & \multicolumn{2}{c}{ SGPT } \\
\cline { 3 - 6 } & & Normal & Meningkat & Normal & Meningkat \\
\hline >75\% dari nilai normal & 23 & 15 & 8 & 17 & 6 \\
$<75 \%$ - $250 \%$ dari nilai normal & 1 & 0 & 1 & 0 & 1 \\
$<50 \%$ - $\geq 25 \%$ dari nilai normal & 1 & 1 & 0 & 1 & 0 \\
$<25 \%$ dari nilai normal & 5 & 4 & 1 & 5 & 0 \\
\hline
\end{tabular}

Data pemeriksaan kadar SGPT menunjukkan sebanyak 23 orang $(76,67 \%)$ memiliki kadar SGPT normal $(<41 \mu / \mathrm{L})$. Sedangkan 7 orang lainnya $(23,33 \%)$ mengalami peningkatan kadar SGPT. Peningkatan kadar SGPT 1-3 kali normal dapat menunjukkan kondisi klinis seperti perubahan lemak dalam organ hati, penyalahgunaan alkohol, sirosis, mononukleosis, obat-obatan seperti statin, aspirin, barbiturat dan obat HIV. Peningkatan kadar SGOT dan SGPT kurang dari 1,5x dari nilai normal tidak selalu menunjukkan adanya gangguan fungsi hati. ${ }^{3,22}$

Hasil uji normalitas menunjukkan bahwa kadar SGOT dan SGPT tidak terdistribusi normal, sehingga digunakan analisis non parametrik yaitu uji korelasi Spearman. Hasil uji ini menunjukkan tidak terdapat korelasi antara paparan pestisida dengan kadar SGOT dengan nilai $p=0,32$, yang artinya tidak terdapat hubungan yang bermakna antara paparan pestisida dengan kadar SGOT. Hasil yang sama ditunjukkan pada korelasi antara paparan pestisida dengan kadar SGPT yaitu dengan $p=0,604$. Hal ini pun berarti tidak terdapat hubungan yang bermakna antara paparan pestisida dengan kadar SGPT.

Fakta di atas diakibatkan oleh paparan pestisida yang masuk kedalam tubuh petani belum mencapai dosis yang bersifat hepatotoksik sehingga efek hambatan pestisida organofosfat terhadap enzim asetilkolinesterase ringan, radikal bebas yang terbentuk sedikit dan tidak menimbulkan kerusakan pada sel hati. Dampak peggunaan pestisida tergantung pada dosis yang digunakan. ${ }^{19}$ Hal ini berhubungan dengan frekuensi penggunaan pestisida dan penggunaan APD. ${ }^{13}$ Frekuensi penggunaan pestisida oleh petani yang menjadi sampel pada penelitian ini tergolong rendah dan semuanya menggunakan APD walaupun tidak lengkap, sehingga dampak negatif yang ditimbulkan akibat penggunaan pestisida menjadi ringan.

Dosis paparan pestisida yang dapat mengakibatkan gangguan fungsi hati pada manusia masih belum diketahui dengan pasti karena percobaan pada beberapa penelitian sebelumnya dilakukan pada hewan coba. Dosis yang efektif pada hewan coba sulit untuk diestimasikan pada manusia karena efek beracun suatu zat kimia akan berbeda antar spesies. ${ }^{9}$ Selain itu organ hepar mampu melakukan regenerasi lebih cepat dibandingkan dengan organ yang lain. ${ }^{3,23}$

Faktor lain yang mengakibatkan tidak terdapatnya hubungan yang bermakna antara paparan pestisida dengan kadar SGOT dan SGPT adalah jenis pestisida yang digunakan. Pada penelitian ini pestisida yang digunakan adalah organofosfat dan karbamat. Tingkat toksisitas kedua pestisida tersebut masuk kategori menengah atau kategori 2 berdasarkan klasifikasi dari US Enviromental Protection Agency. ${ }^{6}$ Selain itu, golongan pestisida ini memiliki biodegradasi yang lebih baik dibandingkan dengan pestisida golongan organoklorin sehingga efek akumulasinya menjadi lebih ringan, apalagi jika digunakan dengan frekuensi rendah. Organoklorin terbukti dapat mengakibatkan kerusakan sel termasuk sel hepar. Kerusakan tersebut melalui mekanisme stimulasi terhadap Mitogen Activated Protein Kinase Pathway (MAPK) yang berhubungan dengan apoptosis. ${ }^{23}$ Efek stimulasi tersebut tidak terjadi pada organofosfat dan karbamat. Dampak merusak organofosfat dan karbamat terhadap sel hepar kemungkinan melalui peningkatan produksi radikal bebas $^{11,12}$ sehingga dapat dihilangkan dengan antioksidan yang biasa dikonsumsi oleh petani, terutama yang berasal dari buah-buahan dan sayuran. Bahan makanan tersebut membantu menghindari kerusakan hati. ${ }^{24}$

Hasil ini berbeda dengan penelitian yang dilakukan oleh Reyes dkk (2018). Penelitian tersebut membuktikan bahwa paparan kronik dengan pestisida mengakibatkan peningkatan kadar SGOT, SGPT dan alkalipospatase. Perbedaan tersebut terjadi karena pada petani yang diteliti menggunakan berbagai macam organopospat (7 jenis) dan berbagai macam organoklorin (14 jenis). Campuran berbagai jenis pestisida tersebut mengakibatkan efek hepatotoksik yang lebih besar sehingga mengakibatkan kadar SGOT dan SGPT meningkat. Ada kemungkinan sampel yang digunakan juga menggunakan pestisida dengan dosis dan frekuensi yang lebih besar. Pernyataan ini dikuatkan dengan residu pestisida yang cukup banyak ditemukan di lingkungan sekitarnya. ${ }^{18}$

\section{SIMPULAN}

Berdasarkan hasil penelitian dan analisis yang telah dilakukan tentang hubungan paparan pestisida dengan kadar SGOT dan SGPT petani di Desa Pakis Kabupaten Jember dapat diambil kesimpulan bahwa tidak terdapat hubungan antara kadar asetilkolinesterase sebagai indikator paparan pestisida dengan peningkatan kadar SGOT dan SGPT.

\section{DAFTAR PUSTAKA}

1. Mohajeri SK, Ahmadipour A, Rahimi HR, and Abdollahi M. Adverse effects of organophosphorus pesticides on the liver: a brief 
summary of four decades of research. Arg Hig Rada Toksikol. 2017; 68: 261-75.

2. Jamal F, Haque QS, Singh S. The influence of pesticides on hepatic and renal functions in occupational sprayers of rural malihabad, lucknow (India). Toxicology: Open access. 2016; 1(1): 1-7.

3. Setiati S, Alwi I, Sudoyo AW, Simadibrata M, Setiyohadi B, dan Syam AF. Buku Ajar Ilmu Penyakit Dalam. Edisi IV. Jakarta: Interna Publishing, 2014. 1023 p.

4. Donham KJ and Thelin A. Agriculture medicine. $2^{\text {nd }}$ ed. New Jersey: John Wiley \& Sons, 2016. 205-250 p.

5. Damalas CA, Koutroubas SD. Farmers' exposure to pesticides: toxicity types and ways prevention. Toxics. 2016; 4(1): 1-10.

6. Sulistyaningsih E dan Marchianti ACM. Agromedicine. Jember: UPT Percetakan dan Penerbitan Unej, 2019. 61-82 p.

7. Marisa dan Pratuna ND. Analisa kadar cholinesterase dalam darah dan keluhan kesehatan pada petani kentang kilometer XI kota Sungai Penuh. Jurnal Kesehatan Perintis. 2018; 5(1): 146-52.

8. Rahmadani NMN, Rachmawati DA, Elfiah U. Perbedaan kadar malondialdehid (MDA) plasma pada petani yang menggunakan pestisida kimia dan petani yang menggunakan pestisida organik. Journal of Agromedicine and Medical Science. 2018; 4 (3): 165-70.

9. Jenni A, Nurjazuli S. Hubungan riwayat paparan pestisida dengan kejadian gangguan fungsi hati (studi pada wanita usia subur di daerah pertanian kota batu). Jurnal Kesehatan Lingkungan Indonesia. 2014; 13(2): 62-65.

10. Rustia HN, Wispriyono B, Susanna D, dan Luthfiah FN. Lama pajanan organofosfat terhadap penurunan aktivitas enzim kolinesterase dalam darah petani sayuran. Makara Kesehatan. 2010; 14(2): 95-101.

11. Tsani RA, Setiani O, dan Dewanti NAW. Hubungan riwayat pajanan pestisida dengan gangguan fungsi hati pada petani di desa sumberjo kecamatan ngablak kabupaten magelang. Jurnal Kesehatan Masyarakat (ejournal). 2017; 5(3): 411-20.

12. Badan Pusat Statistik. Kecamatan Panti Dalam Angka. Jember: BPS Kabupaten Jember. 2019.

13. Budiawan RA. Faktor risiko cholinesterase rendah pada petani bawang merah. Jurnal Kesehatan Masyarakat. 2013; 8 (2):198-206.

14. Han Y, Ma Y, Liu Y, Zhao Z, Zhen S, Yang X, $\mathrm{Xu} \mathrm{Z}$, and Wen D. Plasma cholinesterase is associated with chinese adolescent overweight or obesity and metabolic syndrome prediction. Diabetes, Metabolic Syndrome and Obesity: Targets and Therapy. 2019;12:685-702.

15. Sarkar BR, Dey, Sharma K. The Study of biochemical parameters and histopathological changes in liver of albino rats to find out the effect of extract of sechium edule roots against paracetamol induced hepatic damages. American Journal of Pharmacy and Health Reserch. 2016; 4(4):27-39.

16. Marisa dan Arrasyid AS. Pemeriksaan kadar pestisida dalam darah petani bawang merah di Nagari Alahan Panjang. Jurnal of Sainstek. 2017; 9(1): $14-8$

17. Tambunan AM, Ritonga $\mathrm{H}$, Pasaribu NK. Hubungan kebiasaan merokok, menyirih dan lama bekerja dengan penurunan kadar cholinesterase pada petani di desa gajah pokki Kabupaten Simalungun. 2020 Januari; 2,(1):1-8

18. Reyes JGG and Alegria $\mathrm{H}$. Toxic effects of exposure to pesticides in farm workers in navolato, sinaloa (Mexico). Rev. Int. Contam. Ambie. 2018;34 (3) 505-16.

19. Ramdan IM, Candra KP, Purwanto H. Factors Associated With Cholinesterase Level of Spraying Workers Using Paraquat Herbicide At Oil Palm Plantation In East Kalimantan, Indonesia. Jurnal Kesehatan Lingkungan Indonesia. 2020;19 (1), 2020, 16 - 20

20. Rahmawati YD. Pengaruh faktor karakteristik petani dan metode penyemprotan terhadap kadar kolinesterase. The Indonesian Journal of Occupational Safety and Health. 2017;6(3): 34554.

21. Mahawati1 E, Husodo AH, Sarto AI. Pengaruh teknik aplikasi pestisida terhadap derajat keparahan penyakit paru obstruktif kronis (PPOK) pada Petani. Jurnal Kesehatan Lingkungan Indonesia. 2017;16 (2):37 - 45

22. Reza A, Rachmawati B. Perbedaan kadar SGOT dan SGPT antara subyek dengan dan tanpa diabetes mellitus. Jurnal Kedokteran Diponegoro. 2017;6(2)158-66.

23. Singh Z, Kaur J, Kaur R, Hundal SS. Toxic Effects of Organochlorine Pesticides: A Review. American Journal of BioScience. 2016; 4(3-1): 11-8.

24. Maulida FP, Hairrudin, Sakinah EN. Aktivitas hepatoprotektor cuka apel 'A' terhadap kadar SGOT dan SGPT serum tikus wistar yang diinduksi parasetamol dosis toksik. Pustaka Kesehatan. 2016; 4 (3):603-607. 